\title{
Global Governance Initiative A Critique of the New Partnership for Africa's Development (NEPAD)
}

\author{
Laura Schell-Kerr, Carleton University \\ Department of Political Science, MA Candidate
}

Governance has become the new buzz word in both economic and political science, particularly in terms of what governance means for the international arena. However, it is also a term that is confusing to many. What does it mean to speak about "governance"? Does it refer to the coordination of sectors of the economy, corporate governance, policy networks, "good governance" as a reform objective promoted by the IMF and the World Bank, public management, or public-private partnerships? ${ }^{1}$

One governance initiative which appears to fall under the "good governance" description is The New Partnership for Africa's Development (NEPAD) which is being described as an "African Renaissance". ${ }^{2}$ The NEPAD is an initiative that focuses on neo-liberal economic restructuring, and attempts to tackle corruption and poor governance and to respect "global standards of democracy”, including free elections, accountability and transparency, political pluralism, integrity, and respect for human rights and the rule of law. ${ }^{3}$

The proposal is gaining much support from the West as it is seen as a pledge by new African leaders to lead their countries, and the continent as a whole, on a path to sustainable growth and development, while at the same time participating actively in the world economy and body politic. ${ }^{4}$ The pledge stresses that it is the determination of Africans themselves, in the form of bold and imaginative leadership, to extricate themselves from the malaise of underdevelopment and exclusion in a globalizing world. ${ }^{5}$ This would be an ambitious promise by any national leader, let alone by leaders in a continent such as Africa which has been so plagued by poverty, illness and civil strife. The NEPAD has in fact been criticized for a number of flaws and one such criticism is that, while it may offer the beginning of a philosophical

\footnotetext{
${ }^{1}$ Jon Pierre and B. Guy Peters. "Different Ways to Think about Governance”. Governance, Politics and the State. (New York, USA: St. Martin’s Press., 2000), 14.

${ }^{2}$ Steven Langdon. "NEPAD and the Renaissance of Africa", in David Carment, Fen Osler Hampson and Norman Hillmer, eds., Canada Among Nations: Coping with the American Colossus. (Don Mills, Ontario: Oxford University Press., 2003), 243.

${ }^{3}$ Ibid., 243 \& 246.

${ }^{4}$ New Partnership for Africa's Development (NEPAD), Abuja, Nigeria, October 2001., 1.

${ }^{5}$ Ibid., 1.
} 
change on the continent, the goals and assumptions of the pledge may be untested and unrealistic. $^{6}$

This paper is interested in looking at the question of whether the NEPAD is likely to provide the solutions and organizational capacity that would allow Africa to make its way out and up from its present condition. The question will be posed broadly: Can the NEPAD provide the solutions to Africa's ills with respect to its economic development, entrepreneurial and industrial infrastructure, and its move to democratic accountability?

Using perspectives based on the views of a number of writers, as well as providing case examples of experiences in a few African countries, this paper will illustrate that the NEPAD will not provide the solutions to the challenges plaguing Africa until it first analyzes the specific relationship between economic restructuring and political agency, as well as answering the question as to whether Africa has the entrepreneurial and industrial capacity to compete in a global marketplace.

The paper will be divided into five main sections. Section One will discuss the positive aspects of the NEPAD, as well as the general challenges that the NEPAD is likely to face in order for its objectives to be realized. Section Two will briefly discuss the idea of governance as proposed within the NEPAD. Section Three will address some of the African experiences of neo-liberal economic adjustment programs. Section Four will address whether Africa on the whole has a strong enough entrepreneurial class and the industrial or technological capacity in order to be able to compete in a global market. Section Five will discuss the political considerations of the move toward democracy in the form of multi-party politics within Africa. The purpose of this paper will be to highlight some of the main barriers to a successful implementation of the NEPAD.

\section{I: Introduction to the NEPAD}

The NEPAD emerged from three analogous initiatives: the Millennium Partnership for Africa's Recovery Programme (MAP), the OMEGA Plan, and the Compact for African Recovery

\footnotetext{
${ }^{6}$ Henning Melber. “The New Partnership for Africa’s Development (NEPAD) - Old Wine in New Bottles?” Gender Perspectives on Peace and Conflict Studies. eds. Kari H. Karame and Torunn L. Tryggestad. (Oslo, Norway: Norwegian Institute of International Affairs., June 2002)., 198.
} 
initiated by the executive secretary of the UN Economic Commission for Africa. ${ }^{7}$ In May 2001, the decision was made to merge these three initiatives and in October 2001 the committee renamed it the New Partnership for Africa’s Development and established its secretariat in South Africa. ${ }^{8}$

The agreement addresses a number of issues in Africa such as its historical impoverishment, the cost of Africa's ability to compete, the political will of African leaders, strategies for achieving sustainable development, and bridging the infrastructure gap. ${ }^{9}$ While the NEPAD is a process steered by heads of African states, the UN Economic Commission for Africa provided expert advice on economic issues and developed the concept of "enhanced partnership”, which integrates best practices of both donors and recipients in the aid relationship. ${ }^{10}$ The stress on economics cannot be overstated since after the leading African heads of government had discussed the NEPAD among themselves, they went first to the representatives of private capital and to the Western capitals before consulting with their own people. ${ }^{11}$ This appears to show that the NEPAD is likely to be primarily an economic proposal since it was not created through African civil society engagement and participation. In order for the NEPAD to be a truly African initiative, it would need to have been developed with the voice of Africans at the grass roots and not from discussions of a small number of African elites. Since the concept of democratic governance is one of the main components found within the partnership, the NEPAD itself does not represent well as a model as to how democratic organization should be put into practice.

What makes the NEPAD different from other African proposals is that African leaders have agreed to subject their countries to peer review through the use of the African Peer Review Mechanism (APRM). ${ }^{12}$ The APRM will cover codes, issues, and standards pertaining to sustainable development and governance. It is to be used in assessing the performance of

\footnotetext{
${ }^{7}$ Alex De Waal. “What's new in the 'New Partnership for Africa’s Development'?” International Affairs 78, 3, 463-475., 2002., 466.

8 Ibid., 467.

9 The New Partnership for Africa's Development (NEPAD) (Abuja, Nigeria. 2001), 3, 7, 9, 16 \& 22.

${ }^{10}$ Alex De Waal. “What's new in the 'New Partnership for Africa's Development'?” International Affairs 78, 3, 463-475., 2002., 469.

${ }^{11}$ Henning Melber. “The New Partnership for Africa’s Development (NEPAD) - Old Wine in New Bottles?”. Gender Perspectives on Peace and Conflict Studies. eds., Kari H. Karame and Torunn L. Tryggestad. (Oslo, Norway: Norwegian Institute of International Affairs., June, 2002)., 200.

${ }^{12}$ Ronald Hope Kempe, Sr. "Toward Good Governance and Sustainable Development: The African Peer Review Mechanism”. Governance: An International Journal of Policy, Administration, and Institutions, Vol. 18, No. 2., 283 - 311. (MA,USA: Blackwell Publishing., 2005)., 283.
} 
African countries in terms of their compliance with commitments that reinforce the good governance and sustainable development framework. ${ }^{13}$ The peer review mechanism raises a number of questions such as just how exactly such a review would be implemented, as well as the question of whether a majority of African leaders would agree to such appraisals. Issues of competition, conflict and human rights issues need to be thoroughly addressed in order for the African peer review mechanism to operate at its full potential.

\section{II: Governance and the NEPAD}

Governance within the NEPAD appears to fall between two perspectives of conceptualizing governance; either in terms of the structure and hierarchy of the market, or in terms of governance viewed as a vigorous outcome between social and political actors who determine the dynamics which should be addressed. ${ }^{14}$ This manner of thinking about governance within the NEPAD is merely implied because the agreement makes many references to neo-liberal ideas and terminology while at the same time touting itself as being created from African initiatives and that the success of the initiative will be owned by all Africans. It is important to look a little closer at this concept of the hierarchy of the market and what the concept of governance by community means.

\section{Market as Governance}

The concept of the market as governance is one that views the market as providing better solutions than government can in terms of allowing citizens to choose directly the public services they wish, and because it does not allow politics to distribute resources where they will not be utilized in the most efficient way. ${ }^{15}$ The idea of economics as being a less disordered enterprise than politics is historically quite accepted within economic theory and provides much of the basis for its justification of efficiency. Interestingly, there is not much discussion as to how faulty or inappropriate economic programs can create negative political effects, such as lack of food supply or a sustainable food supply, conflict over scarce resources, political unrest or poverty. There is an undeniable link between economics and politics and to believe that economics is

\footnotetext{
${ }^{13}$ Ibid., 283.

${ }^{14}$ Jon Pierre and B. Guy Peters. "Perspectives on Governance". Governance, Politics and the State. (New York, USA: St. Martin’s Press, 2000), 18 \& 21.

${ }^{15}$ Ibid., 18 \& 19.
} 
“clean” of political interference or political outcomes would do great injustice and disservice to people who have suffered from the negative effects of unsuitable economic programs and management.

Residents of Soweto, South Africa experienced first hand the effects that adopting privatization of their electric utility services brought when policy makers tried to increase private-sector participation in the Eskom electric utility company. ${ }^{16}$ Eskom as a business was of course most concerned with profit-making than it was in public interest issues such as universal access and disconnected electricity in the community. ${ }^{17}$ Without warning, services were disconnected in the community which led to a prolonged struggle, ending with several shootings of Soweto youth by Eskom personnel. ${ }^{18}$ Fear of being harmed or even killed seems to be a high price to pay in order to have privatization measures carried out.

Another example of the lack of a clear distinction between economics and politics is given from a development project of raising chickens in poor villages in Morocco. ${ }^{19}$ Originally, the villagers obtained their chicks from the government but the government had been told by the International Monetary Fund (IMF), that it should not be in the business of distributing the chicks and that the private sector would fill the gap. ${ }^{20}$ Since the death rate of chicks is high within the first two weeks, the private supplier was not willing to give a guarantee on its chicks which led to this promising community development project being shut down. ${ }^{21}$ Examples such as the two just given are not isolated or exceptional cases and occur primarily because the private sector's responsibilities are to its shareholders and its interest is in making profit, while at the same time economists at the World Bank or the IMF are making decisions without input from the people who have to live with such decisions.

Joseph Stiglitz, former chief economist and senior vice president of the World Bank, states that the decisions regarding the Moroccan chicken raising project is a common assumption made by the economists in the IMF who assume that markets will quickly rise to meet every need, rather than recognizing that many government supports have risen to provide services for

\footnotetext{
${ }^{16}$ Guy Massamba, Samuel M. Kariuki and Stephen N. Ndegwa. “Globalization and Africa’s Regional and Local Responses”. Vol 39(1-2):29-45. (London, UK: Sage Publications., 2004), 41.

${ }^{17}$ Ibid, 41 \& 42.

${ }^{18}$ Ibid., 41 \& 42.

${ }^{19}$ Joseph E. Stiglitz. Globalization and its Discontents. (New York, USA: W.W. Norton \& Company, Inc., 2002), $54 \& 55$.

${ }^{20}$ Ibid., 55.

${ }^{21}$ Ibid., 55.
} 
citizens because the market has failed to provide them. ${ }^{22}$ If this is true, and apparently there is a lot of evidence to support Stiglitz's claim, one wonders why African leaders would support such neo-liberal reforms within the NEPAD proposal? The answer may be that donor aid is conditional to Africa meeting particular requirements, with economic restructuring being one such requirement.

\section{Governance as Communities}

A "governance as communities" model believes that communities can, and should, resolve their common problems with a minimum of state involvement. ${ }^{23}$ This description appears to fit the NEPAD with its focus on a "for Africa”, "by Africans" theme. This model further contends that community consent combined with the positive involvement of its members in matters of a collective interest will provide the best answers for governance. ${ }^{24}$ This view of the collective interest is implicit in support of the belief in multi-party politics as creating the much needed democracy for Africa. Communitarian governance is viewed as fostering civic spirit in the community without the need to breed large public bureaucracies, and also rejects the state and market models of governance. ${ }^{25}$ Citizen choice may well foster civic spirit and there has certainly been movement toward freer speech and democratic voting within Africa, but it is unclear as to how communitarian governance would work in Africa. One huge issue which needs to be addressed within the NEPAD is the impact of the HIV/AIDS pandemic upon Africa. HIV/AIDS not only affects the health sector but also education, agriculture, transport, industry, human resources and the economy, dramatically affecting labour, as well as setting back years of economic growth and social progress. ${ }^{26}$ It seems completely unrealistic to expect that Africa can pull itself out of its malaise, rather than asking the question of whether government and foreign involvement will be required in order to not only successfully create economic competitiveness and wealth in the continent, but also more importantly to attempt to halt the decimation of millions of adults affected by HIV/AIDS. Africa is rapidly becoming a continent of millions of

\footnotetext{
${ }^{22}$ Ibid., 55.

${ }^{23}$ Guy Massamba, Samuel M. Kariuki and Stephen N. Ndegwa. “Globalization and Africa’s Regional and Local Responses”. Vol 39(1-2):29-45. (London, UK: Sage Publications, 2004)., 21.

${ }^{24}$ Ibid., 21.

25 Ibid., 21.

${ }^{26}$ http://www.avert.org/aafrica.htm., HIV and AIDS in Africa., January 24, 2007., 1 \&2.
} 
AIDS orphans and how these orphans are supposed to translate into political participants ready to solve Africa's malaise is beyond the scope of comprehension.

\section{III: Neo-Liberalism as the Answer}

Neo-liberal reforms incorporated within a number of countries report evaluations of either mixed, rarely very successful, or sometimes damaging impacts within particular country settings. ${ }^{27}$ Charles Harvey documents the experience of seven countries in sub-Saharan Africa which adopted neo-liberal reforms and finds that, although some have had moderate success in terms of their objectives, most have failed. ${ }^{28}$ Harvey concluded that partial implementation of reform packages or a lack of civil service restructuring can lead to the early demise of such programs. ${ }^{29}$ In his view, liberalization may work better only where the adjustment challenge is small and where distributive changes are not acute. ${ }^{30}$

Charles Harvey’s research thus supports arguments against the implementation of neoliberal reforms, especially in developing countries which have to face larger adjustments than do developed countries with much stronger competitive and state supported resources that enable them to ride out the time of adjustment. Again, one has to wonder why the creators of the NEPAD have not questioned these economic policies when there has been ample evidence at this point to demonstrate their detrimental effects.

Ghana is often cited as a “miracle” in the World Bank’s assessment of economic adjustment in Africa, even though Ghana’s macroeconomic managers have emerged as some of the most vocal critics of the Fund-Bank adjustment design. ${ }^{31}$ Joseph Abbey, speaking to the IMF in 1989, on the occasion of the nomination of Ghana and New Zealand as the most successful examples of economic adjustment, stated that Ghana's experience clearly demonstrates that radical changes need to take place in the thinking and formulation of adjustment programs,

\footnotetext{
${ }^{27}$ Christopher Colclough. "Structuralism versus Neo-Liberalism: An Introduction”, in Colclough, Christopher and Manor, James, eds. States or Markets? Neo-Liberalism and the Development Policy Debate. (Oxford, UK: Clarendon, 1991), 12.

${ }^{28}$ Ibid., 13.

${ }^{29}$ Ibid., 13.

${ }^{30}$ Ibid., 13.

${ }^{31}$ Eboe Hutchful. "Adjustment in Africa and Fifty Years of the Bretton Woods Institutions: Change or Consolidation?” Canadian Journal of Development Studies, XV1, 3, 1995., 407.
} 
particularly in the pacing and sequencing of reforms, as well as in the approach to the social and political impacts of adjustment. ${ }^{32}$

Jerry Rawlings in 1993 admitted that adjustment has made a change in Ghana’s economic situation; “but it's been very costly. There are times when I ask myself: The things that they prescribe for all these countries that want their assistance - could their own countries bear those prescriptions for half a day. ... [Ghanaians have] traveled all the worst possible roads and decided we have no choice but to pull up our bootstraps and get going, no matter the cost. We've got to do something about our situation." ${ }^{33}$ Rawlings's lament may very well be the incentive behind the leadership of the NEPAD - that the leaders feel the adjustments are happening anyway and now that aid is tied to accountable and democratic action, Africa may as well as be sitting at the table when the future of the continent is being decided.

The economic context of the political reforms which have been undertaken in Africa since the late 1980s has been influenced mainly by neo-liberal market ideology. ${ }^{34}$ Arguments have been made that the complications created by the continuing implementation of structural adjustment programmes have failed to reverse economic decline in Africa, while at the same time exacting huge social and political costs. ${ }^{35}$

Zambia's experience of IMF-influenced structural adjustment policies led to rising discontent from its citizens which led to the establishment of multi-party democracy in 1991, with a subsequent electoral defeat by the new Movement for Multi-Party Democracy (MMD). ${ }^{36}$ The newly elected government then executed one of the most radical programmes of economic liberalization in sub-Saharan Africa - exchange controls were removed, major cuts were made to public expenditure, and more than 250 parastatals, 85\% of the Zambian economy, were privatized. ${ }^{37}$ While many observers realized that a number of job losses and company closures

\footnotetext{
${ }^{32}$ Ibid., 407.

${ }^{33}$ Barbara Gullahorn Holecek, “Paying the Piper: conversations with Jerry Rawlings,” Transition, Issue 62, 1993. in Eboe Hutchful. "Adjustment in Africa and Fifty Years of the Bretton Woods Institutions: Change or Consolidation?”. Canadian Journal of Development Studies, XV1, 3, 1995., 408.

${ }^{34}$ Adebayo O. Olukoshi. "Economic Crisis, Multipartyism, and Opposition Politics in Contemporary Africa”. in The Politics of Opposition in Contemporary Africa, (Uppsala: Nordiska Afrikainstitutet, 1998), 11.

35 Ibid., 12.

${ }^{36}$ Miles Larmer. "Reaction and Resistance to Neo-liberalism in Zambia”. Review of African Political Economy. No. 103:29-45., ROAPE Publications Ltd., 2005., 30.

37 Ibid., 30.
} 
were inevitable, economic openings have not resulted in significant private Zambian or foreign investment. $^{38}$

Joyce Nonde, the ZUFIAW General Secretary expressed the labour movements perspective on what went wrong:

... we expected so much to be done, but what did we see? Everything was done in a hurry. There was asset stripping, and there was selling of institutions at a very low price to dubious people, and the workers who were laid off were not paid, they were just thrown into the streets. ... What are you doing, you're creating poverty ... the country has gone backwards, in terms of poverty, in terms of unemployment, ... we blame the IMF and World Bank for having put conditionalities and making the Government rush, into selling these things. ... They are taking advantage of this weak government, which is looking for money.

The above example documenting Zambia's experience provides further evidence of the link between economics and politics, while also indicating that some of these economic restructuring programs create the very poverty that they are supposed to alleviate. Even with indications that adjustment programs were causing harm in Zambia, such programs were highly praised in the 1998 World Bank study, Privatization in Africa ${ }^{40}$ which looked at such privatization schemes within ten sub-Saharan countries and evaluated them on a basis of eight indicators. ${ }^{41}$

Since numerous writers had already been questioning the effectiveness of neo-liberal reforms, particularly in application to their usefulness in developing countries, it pleads the same question as posed within the preceding sections. Why were the economic adjustments imposed by the World Bank and the IMF not questioned by the African leaders who designed the NEPAD?

\section{IV: Barriers to Entrepreneurial Class Development}

Post-independence rulers in Africa have frequently dispensed government-controlled economic resources - credit, licenses, jobs, contracts, and social services to select groups and for persons whose support they wished to secure. ${ }^{42}$ African rulers have used access to public resources as a

\footnotetext{
38 Ibid., 30.

${ }^{39}$ Ibid., 31 \& 32.

40 (Campbell White and Bhatia, 1998) in John Craig. "Evaluating Privatization in Zambia: A Tale of Two Processes”. Review of African Political Economy No. 85:357-366., ROAPE Publications Ltd., $2000 ., 359$.

${ }^{41}$ Ibid., 359.

${ }^{4}$ Andrew M. Mwenda and Roger Tangri. "Patronage Politics, Donor Reforms, and Regime Consolidation in Uganda. African Affairs, 104/416, 449-467., 2005., 449.
} 
key method for maintaining allegiance and political support. ${ }^{43}$ Donor money has been seen to reproduce this practice of patronage politics in Uganda despite donor reforms, since the political actors have erected an expansive and expensive government bureaucracy in order to provide jobs for their supporters. ${ }^{44}$

Uganda's example of patronage politics is common throughout Africa and is a difficult practice to change since there is an extensive history of the practice throughout most of the continent and because there have traditionally been so few resources or other opportunities for advancement. Access to the state purse thus becomes a means to have some semblance of a decent life.

Governments within the African continent have also not exhibited the capacity to control inefficient or unprofitable industries and have consistently been influenced by powerful coalitions of workers and managers who benefit from the state purse. ${ }^{45}$ While this reality might be used as an argument supportive of economic restructuring, it isn’t clear that such reforms would lead to better management of industries.

In the Kenyan manufacturing industry, Africans own very few medium or large-sized manufacturing firms, instead these firms are predominantly owned by multinational corporations (MNCs), Kenyan Asians, or government parastatals. ${ }^{46}$ This factor has critically impeded the recognition of interests between political circles and local industrialists with the end result being that economic policies and bureaucratic decisions are frequently unfavourable to the nation's long-term industrialization. ${ }^{47}$ The most fundamental weakness of the Kenyan African capitalist class was that it was not able to actually form itself into a class because it did not have a shared project for a transition to sustainable capitalist development. ${ }^{48}$ Rather than develop the political foundations capable of organizing class interests and attaching other groups to itself through leadership, it continued to rely on surrendering political power to single individuals. ${ }^{49}$ While one cannot generalize Kenya’s experience to all African countries, it is common within many

\footnotetext{
43 Ibid., 449 \& 450.

${ }^{44}$ Ibid., 464.

${ }^{45}$ Michael F. Lofchie. “The New Political Economy of Africa”., in Apter, David E., and Rosberg, Carl G. Political Development and the New Realism in sub-Saharan Africa. (Charlottesville, USA: University of Virginia Press, 1994), 180.

${ }^{46}$ Colin Leys. "Learning from the Kenya Debate”., in Apter, David E., and Rosberg, Carl G. Political Development and the New Realism in sub-Saharan Africa. (Charlottesville, USA: University of Virginia Press, 1994), 235.

${ }^{47}$ Ibid., 235.

${ }^{48}$ Ibid., 237.

${ }^{49}$ Ibid., 238.
} 
countries in Africa that the entrepreneurial classes have frequently been foreign or colonial-based or have some dependence upon external investment.

Two other factors which affect the member base of a business class in Africa are the HIV/AIDS pandemic and the "brain drain” away from Africa. HIV/AIDS has been decimating the adult population throughout many parts of Africa, negating the effects of decades of development efforts. It would be ludicrous to believe that the orphan children left behind from the pandemic are likely to be able to compete economically and politically within an international market.

The second factor is that many well-educated African professionals are deciding to leave the continent in order to pursue what they hope to be a better standard of living. This means that those who do have access to higher education are leaving Africa and putting their education to use elsewhere. If in fact an entrepreneurial class is missing throughout much of Africa, how does this effect the vision and hope incorporated within the promise of the NEPAD?

\section{V: Political Transformation - Moves toward Multi-Party Democracy}

Africa began to experience pressure to politically reform democratically from the late 1980s with the concept of reform based upon the right of citizens to be entitled to vote, and that opposition parties would serve as institutionalized watch-dogs to keep the ruling party in check. ${ }^{50}$ Other factors influencing the move to multi-party democracy were economic crises and sharp declines in public revenues which led to further cuts in social and welfare spending as most African governments adopted austerity policies aimed at dealing with their worsening economic position. ${ }^{51}$ These crises had the result of strengthening state authoritarianism, partly because the state had a diminished capacity to meet the needs of its citizens, but also because the imposition of austerity measures often provoked riots and strikes. ${ }^{52}$ Governments became preoccupied with repressing all opposition to their rule and security increasingly became the essence of governance that allowed as little room as possible for independent political action or for the promotion of human rights and civil liberties (Bangura, 1992; Mustapha, 1988). ${ }^{53}$

A key component in the NEPAD's objectives is its interest to implement

\footnotetext{
${ }^{50}$ Adebayo O. Olukoshi. "Economic Crisis, Multipartyism, and Opposition Politics in Contemporary Africa. The Politics of Opposition in Contemporary Africa. (Uppsala: Nordiska Afrikainstitutet, 1998), 19.

${ }^{51}$ Ibid., 20.

${ }^{52}$ Ibid.

${ }^{53}$ Ibid.
} 
further internal political and democratic reforms within Africa as a response not only to donor "political conditionality" but also in response to domestic pressures within Africa from citizens who want to see change. ${ }^{54}$ Claude Ake states:

The ordinary people of Africa are supporting democracy as "a second independence". This time they want independence not from the colonial masters, but from indigenous leaders. They want independence from leaders whose misrule has intensified their poverty and exploitation to the point of being life threatening. And they are convinced that they cannot now get material improvement without securing political empowerment and being better placed to bring public policy closer to social needs. ${ }^{55}$

These changes were viewed as a consequence of widespread domestic pressure for reform, as well as from the influence of an international climate which became more favorable and tolerant of internal political reforms in Africa since the fall of the Berlin Wall in $1989 .{ }^{56}$ Whereas in 1989, 38 out of the 45 states in sub-Saharan Africa were under one-party or military rule, a year later in 1990, over half of them had committed to hold multi-party elections. ${ }^{57}$

Between 1990 and 1994, 31 out of 42 sub-Saharan African countries embraced one variant or the other of democratic political systems and held competitive elections which resulted in the defeat of 14 incumbent governments, some of them which had been dominated by people who had been in power since their country attained independence and who had managed to erect elaborate structures to preserve their political power. ${ }^{58}$ While democratic choice can certainly be viewed as a move towards political change, Africa has experienced several difficulties with the move to free elections and the emphasis on multi-party politics.

These seemingly new initiatives have not meant that corruption or authoritarianism has left the political arena in Africa. In fact, many donor countries and international financial institutions (IFIs) continue to deal with African countries that are known to have autocratic and/or corrupt rule. The following are some examples.

\footnotetext{
${ }^{54}$ Ibid., 9.

55 John S. Saul. "For Fear of Being Condemned as Old Fashioned”: Liberal Democracy vs. Popular Democracy in Sub-Saharan Africa”. Review of African Political Economy. (No. 73: ROAPE Publications Ltd., 1997$)$, 349.

56 Ibid., 9.

${ }^{57}$ (Guardian (London), September 11, 1990) in Adebayo O. Olukoshi. "Economic Crisis, Multipartyism, and Opposition Politics in Contemporary Africa. The Politics of Opposition in Contemporary Africa. (Uppsala: Nordiska Afrikainstitutet, 1998), 9.

58 (Bratton, 1995) in Adebayo O. Olukoshi. "Economic Crisis, Multipartyism, and Opposition Politics in Contemporary Africa. The Politics of Opposition in Contemporary Africa. (Uppsala: Nordiska Afrikainstitutet, 1998), 9.
} 
Zambia in 1991 was praised by western donor countries and IFIs as a beacon for political transformation across the continent of Africa, primarily because of its transition to multi-party political competition and open elections. ${ }^{59}$ However many observers argue that multi-party political competition is not in itself adequate for political democracy and that it may result in no more than free competition of elites for political power. ${ }^{60}$ Nyong'o argues that "in the absence of a political culture of participation and accountability, multi-party democracy is likely to remain confined to competition among elites to the exclusion of the masses.”61

In Zambia, almost as soon as the newly elected Movement for Multi-Party Democracy (MMD) was installed, a "shoot on sight” policy was initiated to counteract rising crime, numerous reports were filed on unwarranted arrests, 30 police inflicted deaths were reported within a period of nine months, and the openness of the media was curtailed with threats of firing if reporters did not file positive reports about the government. ${ }^{62}$

The West continued to support the MMD government, even though there was growing evidence in the local press and among individuals of the poor performance of this government, as well as substantiation to claims regarding corruption scandals, the "drug crisis”, the agricultural marketing disaster, the collapse of industrial production, and the decimation of the social infrastructure. ${ }^{63}$ The World Bank representative to Zambia, as well as the UK Ambassador, expressed common sentiments regarding Zambia as a model for other countries in Africa. ${ }^{64}$ Some commentators perceived that Western demands for good government were no more than “the breaking of state power and the 'opening up' of the economy to capitalist development”. 65 While it is generally known that it is not beneficial to pour donor aid into governments which are corrupt, it is difficult to understand why the World Bank and the IMF would choose to ignore such poor behavior in a receiving country and then hold that country up as a standard to which other African countries should strive. It may be that the international financial institutions (IFI)'s are looking to show some African success stories or that democratic practices in Africa are not their primary concern.

\footnotetext{
${ }^{59}$ Dave Bartlett. "Human Rights, Democracy \& the Donors: the First MMD Government in Zambia. Review of African Political Economy No. 87. (ROAPE Publications Ltd., 2001), 83 \& 84.

${ }^{60}$ Ibid., 84.

${ }^{61}$ Ibid.

${ }^{62}$ Ibid., 85 \& 87.

${ }^{63}$ Ibid., 89.

${ }^{64}$ Ibid., 90.

${ }^{65}$ Cliffe and Seddon, 1991. in Ibid., 90.
} 
There is also an argument to be made that structural adjustment programmes themselves represent one of the greatest sources of threat to the current democratic project in Africa. Widespread opposition to structural adjustment implementation feeds into local agitation for political reforms with most of the newly elected governments simply implementing other forms of structural adjustment policies. ${ }^{66}$ It is already known that such policies can create social unrest and protests but if a new government continues to insert other economic plans which are just as painful for civil society, what purpose does multi-party politics serve?

\section{Conclusion}

While an initiative such as the NEPAD can be praised for its claim to have Africans themselves take responsibility for the recovery and progress of the African continent, this writer feels that not only are the objectives within the NEPAD too large and ambitious in order to be workable, but not enough of the right questions and challenges to the initiative are being asked by African citizens nor the creators of the proposal. It is also not clear that the NEPAD is a true African oath since civil society was not consulted prior to the process.

Throughout the paper there has been recurring evidence of a connection between economics and politics which contradicts the assertions of economists that economics is "clean" from political influence or negative social and economic outcomes. The question of whether the NEPAD is a system of market or communitarian governance poses problems as well. Both types of governance have challenges. Neither form of organization believes in strong government involvement, neither do these forms take a position that views one party political regimes as perhaps being temporarily necessary in order to provide stability within particular African countries. At the same time the history of patronage politics in Africa has, and will continue to slow down truly democratic systems. It is also very uncertain as to just how African citizens would be able to participate in and supervise any communitarian type of governance.

Neo-liberalism in practice has also been shown to not provide the much needed answers for Africa and has likely been a contributing factor to more injury to Africa's people. It would be difficult enough to try to form a strong entrepreneurial class within Africa based on the continent's colonial history, its reliance upon raw external resources for economic advancement

\footnotetext{
${ }^{66}$ Adebayo O. Olukoshi. "Economic Crisis, Multipartyism, and Opposition Politics in Contemporary Africa. The Politics of Opposition in Contemporary Africa. (Uppsala: Nordiska Afrikainstitutet, 1998), 12 \& 13.
} 
as well as regional conflicts which turn away potential investors, but to add into this mix the impact of HIV/AIDS upon the social, economic and political fabric of the continent seems to tip the scale more in favor of Africa needing interventionist social and health focused government planning rather than any market-driven "hands-free” public administration. An industrial base heavily weighted in favor of multi-national corporations and foreign investors also certainly affects African claims to indigenous efforts to create change on the continent.

While indigenous ownership and involvement is vital to the economic and political transformation of Africa, the NEPAD, as it stands now, does not provide the much needed answers to Africa's problems. Africa is not only severely burdened by debt crises, and the HIV/AIDS health pandemic, but the continent also does not have a strong enough industrial or technological base in order to allow it to compete in the international arena. The leaders of this partnership have provided the shell of a possible framework for Africa's future but they need to ask more questions, especially from the International Financial Institutions.

Solutions to the challenges that Africa presently faces seem most likely to be found within actions that require more and not less government involvement as well as upon a continued reliance on external aid and support in terms of helping to curb the HIV/AIDS pandemic. Africa's current predicaments do not seem to suggest that the time is appropriate for economic liberalization schemes. Only if the right questions are first asked and solutions found, does the NEPAD hold any possibility for a truly new way for Africa. 


\section{BIBLIOGRAPHY}

Apter, David E. and Rosberg, Carl G. Political Development and the New Realism in Sub-Saharan Africa. Charlottesville, USA: University of Virginia Press, 1994.

Avert.Org. HIV and AIDS in Africa., January 24, 2007. http://www.avert.org/aafrica.htm

Bartlett, Dave. "Human Rights, Democracy and the Donors: the First MMD Government in Zambia.” Review of African Political Economy., No. 87:83-91., 2001.

Carment, David, Fen Osler Hampson, Norman Hillmer. Canada Among Nations: Coping with the American Colossus. Don Mills, Ontario: Oxford University Press., 2003.

Craig, John. "Evaluating Privatisation in Zambia: A Tale of Two Processes". Review of African Political Economy. No. 85:357-366., 2000.

Culclough, Christopher and James Manor, eds., States or Markets? Neo-Liberalism and the Development Policy Debate. Oxford, UK: Clarendon, 1991.

De Waal, Alex. "What's new in the "New Partnership for Africa’s Development”?" International Affairs 78, 3, 463-475., 2002.

Hutchful, Eboe. "Adjustment in Africa and Fifty Years of the Bretton Woods Institutions: Change or Consolidation?” Canadian Journal of Development Studies, XV1, 3, 391-417, 1995.

Karame, Kari H., and Torunn L. Tryggestad. Gender Perspectives on Peace and Conflict Studies., Oslo, Norway: Norwegian Institute of International Affairs, 2002.

Kempe, Ronald Hope, Sr. "Toward Good Governance and Sustainable Development: The African Peer Review Mechanism”. Governance: An International Journal Of Policy, Administration, and Institutions. Vol. 18, No. 2, pp. 283 - 311., MA: USA: Blackwell Publishing., 2005.

Larmer, Miles. "Reaction and Resistance to Neo-liberalism in Zambia". Review of African Political Economy. No. 103:29-45. ROAPE Publications Ltd., 2005.

Massamba, Guy, Samuel M. Kariuki and Stephen N. Ndegwa. "Globalization and Africa’s Regional and Local Responses”. Vol 39(1-2):29-45. London, UK: Sage Publications., 2004.

Mwenda, Andrew and Roger Tangri. "Patronage Politics, Donor Reforms, and Regime Consolidation in Uganda”. African Affairs, 104/416, 449-447., 2005. 
Olukoshi, Adebayo O. “Economic Crisis, Multipartyism, and Opposition Politics in Contemporary Africa.” The Politics of Opposition in Contemporary Africa. Uppsala: Nordiska Afrikainstitutet, 1998.

Pierre, Jon and B. Guy Peters. Governance, Politics and the State. St. Martin’s Press, New York, USA, 2000.

Saul, John S. "For Fear of Being Condemned as Old Fashioned”: Liberal Democracy vs. Popular Democracy in Sub-Saharan Africa”. Review of African Political Economy. No. 73: 339-353, 1997.

Stiglitz, Joseph. Globalization and its Discontents. New York, USA: W.W. Norton \& Company., 2002.

The New Partnership for Africa’s Development (NEPAD). Abuja, Nigeria. 2001 http://wwwnepad.org.ng/about_nepad.htm 